\title{
Sultan II. Abdülhamid Dönemi Osmanl1-Rus İlişkilerinde Mektup Diplomasisi
}

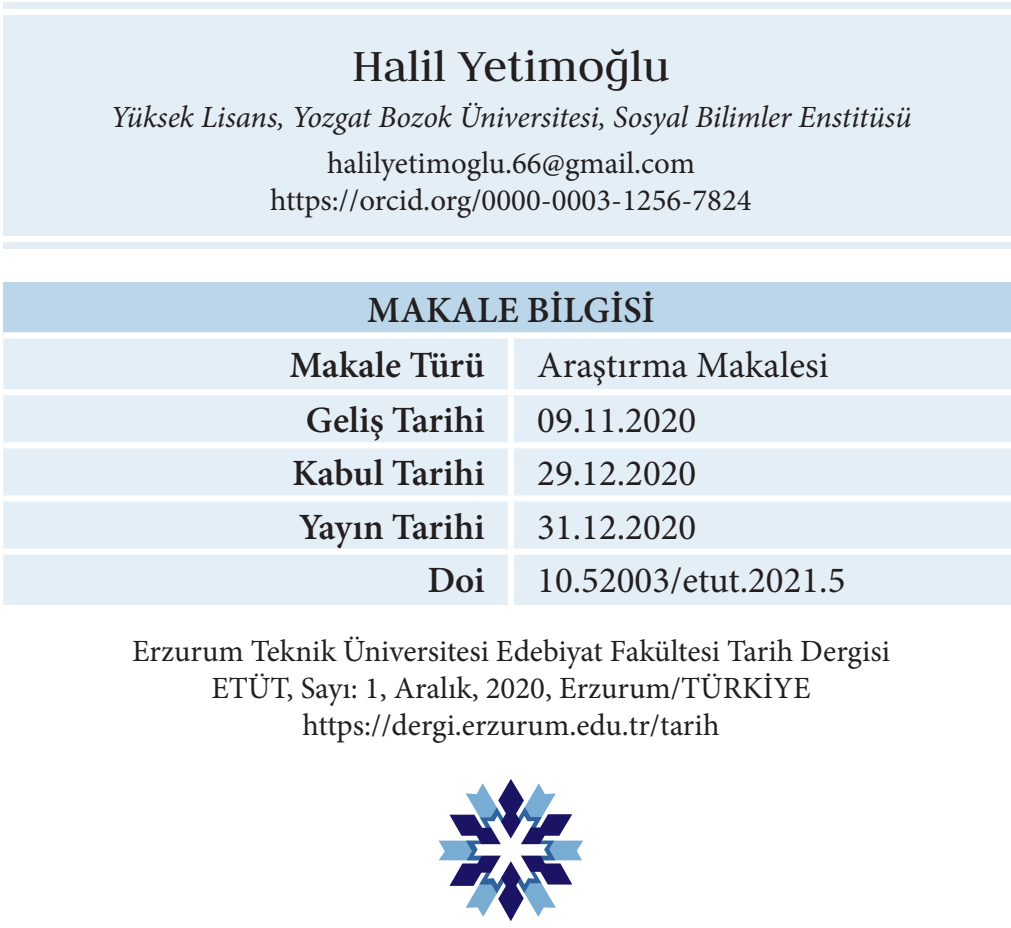

\section{Letter Diplomacy in the Ottoman-Russian Relations in the Abdulhamid II Period Activities}

\author{
Halil Yetimoğlu \\ Master's Degree, Yozgat Bozok University, Social Science Institute \\ halilyetimoglu.66@gmail.com \\ https://orcid.org/0000-0003-1256-7824
}

\begin{tabular}{|r|l|}
\hline \multicolumn{2}{|c|}{ ARTICLE INFORMATION } \\
\hline Article Types & Research Article \\
\hline Received Date & 09.11 .2020 \\
\hline Accepted Date & 29.12 .2020 \\
\hline Date Published & 31.12 .2020 \\
\hline Doi & $10.52003 /$ etut.2021.5 \\
\hline
\end{tabular}

Erzurum Technical University, Faculty of Letter, History Journal ETUT, Issue: 1, December 2020, Erzurum/TURKEY

https://dergi.erzurum.edu.tr/tarih 


\title{
Sultan II. Abdülhamid Dönemi Osmanlı-Rus İlişkilerinde Mektup Diplomasisi
}

\author{
Halil Yetimoğlu
}

\begin{abstract}
Öz
$\mathrm{Bu}$ çalışmanın amacı, Abdülhamid II döneminde Osmanlı-Rus ilişkilerinde mektup diplomasisinin önemini ortaya çıkarmaktır. $\mathrm{Bu}$ araştırmada, mektupların önemi ve iki ülke ilişkilerine olan katkısı değerlendirilmiştir. Sultan II. Abdülhamid dönemi Osmanl1-Rus ilişkilerinde diplomasinin önemli bir yeri bulunmaktadır. 1877-1878 Osmanlı-Rus harbi sonrasında iki ülke arasında diplomatik ilişkiler başlamıştır. Mektup diplomasisi, bu süreçte büyük önem kazanmıştır. Ermeni sorunu, Girit meselesi, Bulgaristan ve Doğu Rumeli olaylarında mektup diplomasisi büyük işlev görmüştür. Bunun yanı sıra elçi tayini, doğum günü kutlaması ve taç giyme merasimi nedeniyle mektuplar gönderilmiştir. Padişah II. Abdülhamid, özellikle Rusya ile diplomatik münasebetlerin devamı için büyük çaba sarf etmiştir.
\end{abstract}

Anahtar Kelimeler: II. Abdülhamid, III. Aleksandr, II. Nikola, Osmanl1, Rus, Mektup, Diplomasi.

\section{Letter Diplomacy in the Ottoman-Russian Relations in the Abdulhamid II Period}

\begin{abstract}
The aim of this study is to reveal the importance of letter diplomacy in Ottoman-Russian relations during the reign of Abdulhamid II. In this study, the importance of letters and their contribution to the relations of those two countries are evaluated. Diplomacy has an important place in Ottoman-Russian relations during the Abdulhamid II period. Diplomatic relations between two countries began after the 1877-1878 Ottoman-Russian War. Letter diplomacy has gained great importance in this process. Letter diplomacy played a major role in the Armenian problem, the Cretan issue, and the events of Bulgaria and Eastern Rumelia. In addition, letters were sent for the appointment of ambassadors, birthday celebration and coronation. Sultan Abdulhamid II made a great effort in order to maintain diplomatic relationships with Russia.
\end{abstract}

Keywords: Abdulhamid II, Alexander II, Nicola II, Ottoman, Russia, Letter, Diplomacy. 


\section{Giriș}

Osmanlı padişahlarının diplomaside mektup kullanmaya başlaması devletin ilk dönemlerine kadar geriye gitmektedir. ${ }^{1}$ Fakat devletin ilk dönemlerinde daha çok siyasi ve ticari içerikli mektuplar görülmektedir. Osmanl1-Rus ilişkileri bağlamında ilk mektup, Rus Knezi III. Ivan tarafindan II. Bayezid'e gönderilen 31 Ağustos 1492 tarihli mektuptur. $\mathrm{Bu}$ olay aynı zamanda Osmanl1-Rus diplomatik ilişkilerinin başlangıcıdır. ${ }^{2}$ Söz konusu mektupta Çar, Sultana; “...Müslüman hükümdarlar arasında sen büyük hükümdarsın, Türk ve Acem hükümdarları üstünde senin iraden, sen kara ve denizlerin hükümdarı, Sultan Bayezid..." ifadelerine yer verirken kendisinden “... İvan, Tanrının acımasıyla bütün Rusya'nın baba ve dededen biricik haklı hükümdarı ve kuzeyden doğuya kadar pek çok toprağın hükümdarı...” şeklinde bahsetmiştir. Rus Çarının bu hitap şekli, Sultanın unvanlarının istenilen şekilde yazılmadığı için Osmanlı bürokrasisi tarafından uygun görülmemiştir. III. İvan 1497'de Mihail Plesçeyev ile gönderdiği diğer bir mektubunda hitap şeklini değiştirerek “... Anadolu ve Rum toprakları, Akdeniz, Karadeniz ve Karaman toprakları, Küçük Roma (Rumeli) ve daha pek çok yerin hükümdarı...” ifadelerine yer vermiştir.

Bu dönemde Rus Knezi III. Ivan, Osmanlı Devleti ile temaslarını Kırım Hanı vasitasıyla sürdürmüştür. Doğrudan İstanbul'a ilk elçi III. Ivan döneminde Yavuz Sultan Selim'in cülusunu tebrik etmek ve aynı zamanda iyi ilişkiler kurmak için gönderilmiştir. ${ }^{3}$ Yavuz Sultan Selim ise elçisiyle birlikte 3 adet mektup göndermiştir. İlk mektubunda Rus knezine "dostuma dost düşmanıma düşman" şeklinde hitapta bulunmuştur. ${ }^{4}$

Osmanlı-Rus ilişkileri inişli-çıkışlı devam ederken ilk defa bir Rus çarı tarafından Osmanlı sultanına tehdit mektubu gönderilmiştir. Rus çarı Aleksey Mihayloviç 1672'de Sultan IV. Mehmed'e gönderdiği mektupta; Lehistan

\footnotetext{
${ }^{1}$ Bu çalışma, Prof. Dr. Yunus Özger danışmanlığında tamamlanan, Halil Yetimoğlu, "Sultan II. Abdülhamid'in Rus İmparatorları İle Mektup Diplomasisi”, Bozok Üniversitesi Sosyal Bilimler Enstitüsü, Yozgat 2019 künyeli Yüksek Lisans Tezinden üretilmiștir.

2 Akdes Nimet Kurat, Rusya Tarihi Başlangıçtan 1917'ye Kadar, Türk Tarih Kurumu Yayınları, Ankara 2014, s. 132-133; Halil İnalc1k, “Osmanl1-Rus İlişsileri 1492-1700”, Türk-Rus İlişkilerinde 500 Yll 1492-1992 Ankara 12-14 Aralık 1992, Türk Tarih Kurumu Yayınları, Ankara 1999, s. 25-26.

${ }^{3}$ Omeljan Pritsak, "1491-1532 Yıllarında Osmanl1-Moskova İlişkileri”, Türk-Rus İlişkilerinde 500 Yll 1492-1992 Ankara 12-14 Aralı 1992, Türk Tarih Kurumu Yayınları, Ankara 1999, s. 69.

${ }^{4}$ Yücel Öztürk, “Osmanlı Devleti’nin Rusya'ya Yönelik Dış Politikası ve Türkiye-Moskova İlişkileri (16. ve 17. Yüzyıllar), Türk Dış Politikası Osmanlı Dönemi, Ed. Mustafa Bıyıklı, Bilimevi Yayınları, İstanbul 2008, s. 223-224.
} 
seferinden vazgeçmesini istemiştir. Aksi halde tüm Hristiyan devletleri ve İran'1 Osmanlı'ya karşı harekete geçireceğini bildirmiştir. ${ }^{5}$

Bununla birlikte, 1700'lerden itibaren Osmanl1-Rus ilişkilerinde her ne kadar savaşlar yapılsa da dostluk içerikli birçok mektuplaşmanın olduğu da görülmektedir. Özellikle cülus tebriklerinde dostluk içerikli mektuplara sıç̧a rastlanmaktadır. Örneğin Rus Çariçesi I. Elizabeth tahta çıktığını Sultan I. Mahmud'a bildiren mektubunda, dostluk ve barıştan bahsederek bunu devam ettireceğini ve aynı şekilde Sultanın da buna riayet etmesini istemiştir. Ayrıca Sultandan dostluğu teyit eden bir cevabi mektup göndermesini istemiştir. Sultan I. Mahmut da buna uygun bir mektup göndermiştir. ${ }^{6}$

Ayrica Sultan Abdülaziz'in Nureddin ismi verilen bir oğlu dünyaya geldiğinde Rusya imparatoru II. Aleksandr'a bir mektupla bu sevinçli haberi bildirmiştir. İmparator ise gönderdiği tebrik mektubunda Sultan Abdülaziz ile olan dostluğunu belirterek bu doğumu tebrik etmiş ve şehzadenin uzun ömürlü olması temennisinde bulunmuştur. ${ }^{7}$

Sultan II. Abdülhamid Dönemine gelindiğinde ise, iktidarının ilk yıllarında 1877-1878 Savaş1 yapılmış olsa da diplomatik ilişkilerin sürdürülebilmesi adına bir kap1 aralı̆̆1 bırakılmıştır. Bu münasebetle savaşın hemen ardından diplomatik temaslar kurulmaya başlanmış ve iki ülke birbirleri nezdine büyükelçiler tayin etmişlerdir. Hükümdarlar arasında mektuplar ve telgraflar aracıllğıyla diplomatik ilişkiler kurulmuştur.

1878 Berlin Kongresi'nden sonra Osmanlı diplomasi tarihinde önemli bir değişikliğe gidilmiştir. Tanzimat döneminde diplomasinin belirleyici gücü Babıali iken Sultan II. Abdülhamid bu yetkiyi kendi uhdesine geçirmiştir. Babıali ise diplomasinin uygulayıcısı haline gelmiştir. Sultan II. Abdülhamid, her ne kadar Balkan topraklarındaki sorunlarda ve Ermeni meselesinde Rusya ile karşı karşıya gelse de barışçıl politika takip ettiği için çözüm yolu olarak diplomasiye ağırlık vermiştir. Osmanl1-Rus ilişkilerinde hangi meseleler üzerinde mektup diplomasisine başvurulmuş, iki ülke dostluk ilişkilerinin devam ettirilmesinde ne tür bir yol

\footnotetext{
${ }^{5}$ Kurat, Rusya Tarihi, s. 251-252.

6 İsmet Binark, "Başbakanlık Osmanlı Arşivinde Mevcut Name-i Hümayun Defterlerine Göre Osmanl1-Rus Münasebetleri”, Türk-Rus Ilisşkilerinde 500 Yll (1491-1992), TTK Yayınları, Ankara 1999, s. 203.

${ }^{7}$ BOA. (Başkanlık Osmanlı Arşivi). HR. TO (Hariciye Tercüme Odası), 286-28, 26 Şubat 1857.
} 
izlenmiştir? Barışın korunmasında izlenen yol karşılıklı mı olmuş, diplomasi de nasıl bir üslup kullanılmış, diplomatik temaslar hükümdarlar ile sınırlı mı kalmış? Diplomatik temaslar amacına ulaşmış $\mathrm{m}$ ? $\mathrm{Bu}$ sorulara aşağıdaki başlıklar çerçevesinde cevaplar aranmıştır.

\section{Ermeni Sorunu}

Ermeniler, 1890'lı y1llarda Rus ve İngilizlerin desteği ile Anadolu'da isyana kalkışmışlar ve buna karşı Hamidiye Alayları kurulmuştu. Bu durumda çıkarları zedelenen Rusya, Ermenileri göç etmeye teşvik ederek uluslararası kamuoyuna Müslümanların Ermenileri yok edeceği şayiasını yaymaya çalışmıştır. 1894 yılı itibariyle Ermeniler, muhtelif sebeplerle göç etmeye başlamışlardır. Ancak bir zaman sonra Ruslar, topraklarına göçen Ermenilerin maddi sıkıntı çektiklerini belirtilerek, tekrar Osmanlı topraklarına dönmelerini istemiştir. Bu hususta iki ülke arasında diplomatik temaslar kurulmuştur. Ardından Rusya, topraklarındaki Ermenileri kafileler halinde gönderme kararı almıştır. Osmanlı Devleti ise Ermenilerin, Rusya'nın geniş bozkırlarına ve Osmanlı topraklarına göç eden Müslümanların boş bıraktı̆̆ 1 mahallere yerleştirilmesini istemiştir. ${ }^{8}$ II. Nikola, gönderdiği telgrafta, Ermenilerin topraklarında iskân edilmelerinin mümkün olmadığını, “...Kafkasya'ya muhâceret etmiş olan Ermenileri orada alıkoymak benim için mümkün olamayıp..." ifadeleriyle dile getirmiştir. Devletinin sultanla olan dostluğuna vurgu yaparak, Ermenileri senelik on bin kişilik kafilelerle göndereceğini bildirmiştir. ${ }^{9}$ Sultan II. Abdülhamid, iki ülke çıkarlarına uygun bir politika üreterek bu meseleye çözüm bulmaya çalışmıştır. ${ }^{10}$ Rusya'nın İstanbul sefiri Zinovyev ile temaslarını sürdürmüş ve elçinin teşebbüsüyle Ermenilerin bir müddet Rusya'da kalmaları sağlanmıştır. $\mathrm{Bu}$ durumdan memnun olan padişah, memnuniyetini dile getiren bir namesini II. Nikola'ya göndermiştir. Ermenilerin Rusya'dan tasfiyesinin tehir edilmesinin iki ülke açısından önemine dikkat çekmiş, bu durumun Misır Meselesinde Sultan II. Mahmud'a yapılan yardımdan daha mühim olduğunu belirtmiştir. ${ }^{11}$

\footnotetext{
${ }^{8}$ Yetimoğlu, Sultan II. Abdülhamid'in Rus Imparatorları İle Mektup Diplomasisi, s. 57-59.

${ }^{9}$ BOA. Y. PRK. NMH. (Yıldız Perâkende Evrâkı Nâme-i Hümâyûnlar), 7-79, v. 18, 16 Mayıs 1899.

${ }^{10}$ BOA. Y. PRK. NMH. 7-79, v.16, 6 Mayıs 1315 [18 May1s 1899].

11 “... ceddim cennetmekân Sultan Mahmud Han hazretlerinin zaman-l saltanatlarında devlet-i 'âliyyemiz hakkında cedd-i emced haşmetâneleri tarafindan vaki 've tesîrât-ı hasenesi el'ân bâkî olan
} 
Ermenilerin göçü meselesinde Sultan II. Abdülhamid'in bizzat kendisi Rus imparatoru ile temas kurarken, aynı zamanda hususi elçiler göndererek de çözüm bulmaya çalışmıştır. II. Nikola, istirahat için Livadya'ya geldiğinde Turhan Paşa'yı göndererek iradesini bildirmiştir. Ermenilerin ülkede karışıklık çıkardıkları ve asayişi bozdukları bildirilerek, geri dönmelerinin engellenmesini istenmiştir. Rus imparatoru ise Ermenilerin Rus mekteplerinin düzenini bozmaya çalıştıklarını ve onların kendi topraklarında da işleri olmadığını bildirmiştir. Bunun yanında, sultanın isteğini de geri çevirmeyip gerekli tedbirleri alacağını bildirmiştir. ${ }^{12}$ Diğer taraftan Ermeniler, yasal olmayan yollarla Osmanlı topraklarla giriş yapmışlardır. Nihayetinde Tiflis Başkonsolosluğu'nun bildirdiği üzere, Rusya hükümeti cereyan eden bu huzursuzluğa son vermek için Ermenilere vatandaşlık hakkı tanıyacağını bildirmiştir. ${ }^{13}$ Böylece önemli bir sorun, diplomatik yollarla suhuletle çözülmeye çalışılmıştır.

\section{Girit Sorunu}

Rumlar, 1876'da Girit'te isyan ederek özerklik istemişler, 25 Ekim 1878'de Halepa Sözleşmesi yapılarak durum yatıştırılmıştır. Ancak Doğu Rumeli ve Bulgaristan'ın 1885 yılında birleşmesi ve 1896 Ermeni ayaklanmaları, Girit halkının yeniden isyan etmesine yol açmıştır. Yunanistan'ın destek vermesi ile de isyan tüm adaya yayılmıştır. 1897 'de Yunanlılarla yapılan Dömeke Muharebesi'nde Osmanlılar zafer elde etmiştir. Bunun üzerine araya büyük devletler girmiş ve 4 Aralık 1897'de İstanbul Antlaşması imzalanmıştır. Bu antlaşma sonrasında Girit'e vali tayini hususunda Osmanlı Devleti ile Yunanlılar arasında anlaşmazlık çıkmıştır. Yine Avrupalı devletler araya girerek, Osmanlı'ya ültimatom vermişler ve askerlerini Girit'ten bir ay zarfında çekmesini istemişlerdir. ${ }^{14} \mathrm{Bu}$ durum karşısında Sultan II. Abdülhamid, askerlerinin tahliyesinin engellenmesi için II. Nikola'ya telgraf çekerek, diplomatik temasa geçmiştir. Ancak II. Nikola, Girit halkının

\footnotetext{
muâvenet-i dostâneden ziyâde te 'sîrât-ı minnetdârâne hâsıl etmiştir...” BOA. Y. PRK. NMH, 8-7, 1 Eylül 1315 [13 Eylül 1899].

12 “... arzî̀-yl şâhânenin husûlü emrinde tecvîz-i kusûr etmem yine lâzlm gelenlere evâmir-i mukteziyye verilir.” BOA. Y.EE. (Yıldız Esâs Evrâk), 13-19, 23 Teşrinievvel 1317 [5 Kasım 1902].

${ }^{13}$ Osmanlı Belgelerinde Ermeni Rus İlişkileri (1899-1906), C. II, Yay. Haz: Recep Karacakaya ve diğerleri, Başbakanlık Devlet Arşivleri Genel Müdürlüğü Osmanlı Arşivi Daire Başkanlığı Yayını, Ankara 2006, s. 59.

${ }^{14}$ Enver Ziya Karal, Osmanlı Tarihi VIII, Birinci Meşrutiyet ve İstibdat Devirleri (1876-1907), TTK, Yayınları, Ankara 2011, s. 124.
} 
huzursuz olduğunu Osmanlı askerlerinin orada kalması halinde şiddetli çatışmaların yaşanacağını bildirerek, padişahın arzusunun yerine getirilmesinin güç olduğunu bildirmiştir. Aynı zamanda dostlukları gereği Girit'te padişahın hakkını korumak için İngiltere, Fransa ve İtalya ile istişare de bulunarak gereken tedbirleri düşünmekten uzak kalmayacağını belirtmiştir. ${ }^{15}$ Sultan II. Abdülhamid, yeniden telgraf çekerek bu hassas konuda I. Nikola'nın II. Mahmud'a yaptığı yardıma benzer kendisine de yardım edilmesini istemiştir. ${ }^{16}$ Fakat bu girişimlerden bir netice elde edilememiş ve Osmanlı askerleri 5 Kasım 1898'de Girit Adası'ndan çekilmişlerdir. ${ }^{17}$

Büyük devletlerin kararnyla Girit'e Yunan Prensi Yorgi vali olarak tayin edilmiştir. Bu durumu II. Nikola, Sultan II. Abdülhamid'e telgraf çekerek iletmiştir. Geçici komiser olarak Prens Yorgi'nin Girit'e tayin edildiğini, adanın huzur ve asayişini büyük devletlerin üstlendiğini ve kendi amiralleri vasıtasılla yürütülen hükümlerin ise Prens Yorgi tarafından icra edileceğini ifade etmiştir. Nikola, bu görevin Prens Yorgi'ye tevdi edilme nedeninin Girit Adası'nın bir an evvel huzur ve sükûnete kavuşması olduğunu bildirmiştir. Bu konuda dört büyük devletin istişare ettiğini ve Rusya'nın bu kararda tek başına söz sahibi olamayacağını bildirmiştir. Sultan II. Abdülhamid'in buradaki kutsal haklarına, büyük devletlerin zara verme durumunun söz konusu olmadığını ve bu seçimle ilgili Sultanın bir endişe içerisinde bulunmamasını istemiştir. Girit sorununun çözülmesiyle iki ülke ilişkilerinin gelişeceğini ve dostluğun daha da sağlamlaşacağını bildirmiştir. ${ }^{18}$

\section{Bulgaristan ve Doğu Rumeli Sorunu}

13 Temmuz 1878 Berlin Antlaşması ile Bulgaristan üçe ayrılmış fakat Bulgarlar, Büyük Bulgaristan kurma hayalleriyle Müslümanlara zulmetmeye mal ve topraklarına el koymaya, çoğunluğu elde etmek için Türkleri Bulgarlaştırmaya,

\footnotetext{
15 “... Cezîre ahâlîsinin klsm-ı a zamında müşâhid olan eseri galeyân-ı hasmâne nümâyüşlere ve hatta asker-i osmâniye hakkında mu âmelât-ı şedîdeye bâdi olabilir ... bununla berâber memalik-i şâhânelerinin tamâmiyetini muhâfaza etmek kuvvesinde olduğumdan ve zât-l şevket-simât

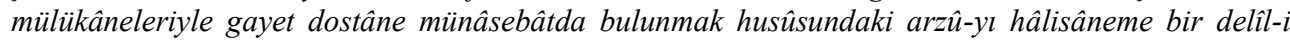
cedîd ibrâz etmek emelinde bulunduğumdan...", BOA, Y. PRK. NMH, 7-98, v. 3, 26 Ekim 1898.

16 “...Büyük pederi haşmetâneleri tarafindan ceddim Sultan Mahmud ve merhûma icrâ olunmuş olan muâvenet-ı 'âliyye misüllü Girid'de hükümdârânımızın eseri bulunan askeriyemizin bekâsını tehdîd eden ahvâlin bertaraf edilmesi husûsunca sezâvar (laylk) buyurulacak muâvenât nâme ...”, BOA. Y. PRK. NMH, 7-98, v.5, 4 Kasim 1898.

${ }^{17}$ Karal, Osmanlı Tarihi VIII, s. 124.

18 “...Girid ahâlîsinin her şeyden evvel bittabi arzu buyuracakları sa'adet hâlini sûret-i kat'iyyede te 'mîne vâsita-ı yegâne add itmek üzere...”, BOA. Y. EE, 114-58, 24 Kasım 1898.
} 
camileri tahrip edip kiliseye çevirmeye başlamışlardır. Sultan II. Abdülhamid, bu hazin duruma son vermek için Rus imparatoru II. Aleksandr'a mektup göndererek, baskıların durdurulmasını istemiştir. Mektupta Müslümanlara yapılan bu muamelenin vahametinden söz etmiştir. Meselenin çözümü için kendisinden yardım talep ederek, Doğu Rumeli ve Bulgaristan'daki Müslüman halkın can, irz ve namuslarının güvence altına alınmasını istemiştir. ${ }^{19}$ II. Aleksandr ise cevabi mektubunda bu olaylar karşısında büyük üzüntü duyduğunu, fakat bu meselenin biraz abartıldığını düşünmüştür. Ancak böylesi bir duruma müsamaha göstermeyeceğini, bu tür şiddet eylemlerine karşı tedbir alınacağını, Bulgaristan'da bulunan Rus komiser ve Rus ordusunun bölgede milliyet ve mezhep fark1 gözetmeksizin halkın huzur ve emniyeti için çalışacağını bildirmiştir. ${ }^{20}$ Öbür taraftan Rusya, Bulgaristan ve Doğu Rumeli’yi birleştirerek Bulgar Prensliği kurmak istemiş ve diğer devletleri bu meseleye dâhil etmemek için sorunu Osmanlı Devleti ile çözmek istemiştir. Bunun için II. Aleksandr, Sultan II. Abdülhamid'e mektup göndermiş ve General Obriçov'u elçi olarak İstanbul'a yolladığını ve Obriçof'un Doğu Rumeli halkına imparator adına nasihatte bulunacağını, Bulgarlara ise Berlin Antlaşması'na uymaları gerektiğini söyleyeceğini bildirmiştir. ${ }^{21}$ Osmanlı Devleti bunu kabul etmiş ve General Obriçof bu vazifeyi yerine getirerek bölgede bir süre sükûnet sağlanmıştır. ${ }^{22}$

\section{4. İstanbul ve Petersburg Elçi Tayinleri}

1877-1878 Osmanlı-Rus Savaşı'nda her iki devlet sefaret temsilcilerini geri çağırmıştı. 3 Mart 1878 Ayastefanos Barış antlaşması yapıldıktan sonra iki ülke arasında ilişkilerin yeniden tesis edilmesi adına elçilerin tayini gündeme gelmiştir. Bu hususta II. Aleksandr, Prens Lubanov Rustovski’yi İstanbul'a büyükelçi tayin ettiğini bildiren bir mektup göndererek elçinin huzura kabul edilmesini ve güven

\footnotetext{
19 “....Bulgarların binlerce ebnâ-yı beşer hakkında icrâ ettikleri mezâlimi tasavvur kâbil değildir. Katli nüfus ve gasb-ı emvâl ve hetk-i irz ve nâmus gibi şeylerin hiçbiri esirgendiği yoktur ...”, BOA. Y. PRK. NMH, 1-29, 7 Şaban 1295 [6 Ağustos 1878].

${ }^{20}$ Mahmud Celaleddin Paşa, Mir'ât-ı Hakîkat, Haz: İsmet Miroğlu, Berekat Yayınları, İstanbul 1983, s. 618 .

21 “...Ceneral Obriçof'u makâsıd-ı sulhperverânem hakkında kimsenin şüphesi kalmamak için Ístanbul'a azîmet'e me'mur eylerim...”, BOA. Y. PRK. NMH, 1-56, 18 Rebiülahir 1296 [11 Nisan 1879].

${ }^{22}$ Karal, Osmanlı Tarihi VIII, s. 105.
} 
duyulmasını istemiştir. ${ }^{23}$ Diplomatik ilişkilerin yeniden tesis edilmesini isteyen padişah, iki mektup göndermiş, Ahmet Şakir Paşa'yı müşir rütbesiyle Petersburg sefaretine tayin ettiğini bildirmiştir. ${ }^{24}$

Prens Lubanov, 18 May1s 1878'de itimatnamesini Sultan II. Abdülhamid'e takdim etmiştir. Okuduğu nutukta, eski dostane ilişkileri yeniden tesis etmek için memur edildiğini bildirmiştir. İki ülke arasında dostluk ve barış için mesai harcayacağını beyan ederek padişaha iltifatlarda bulunmuştur. ${ }^{25}$ Lubanov, üç yıla yakın bir süre görev yapmıştır. Ardından yerine II. Aleksandr'ın özel müşaviri Novikov tayin edilmiştir. II. Aleksandr, mektubunda görev süresi biten Lubanov'un vazifesini layıkıyla yerine getirdiğini söylemiş, ${ }^{26}$ yerine özel müşaviri Novikov’u tayin ettiğini bildirmiştir. ${ }^{27}$ Novikov, 24 Mayıs 1880 'de huzura çıkarak itimatnamesini sunmuştur. ${ }^{28} 14$ Haziran 1883 'te III. Aleksandr, Novikov'un yerine Nelidov'u İstanbul sefaretine tayin etmiştir. III. Aleksandr, Nelidov'u tayin ettiğini bildirdiği mektubunda uzun bir elkâb kullandıktan sonra konuya giriş yapmış ve yeni elçiye güven duyulmasını isteyerek iyi dilek temennisinde bulunmuştur. ${ }^{29}$

Şakir Paşa Petersburg’ta on iki yıl memuriyette kaldıktan sonra 1889 yılında Girit vali vekili olarak görevlendirilmiştir. Yerine ise Çetine sefiri Hüseyin Hüsnü

\footnotetext{
23 “,,prens Lubanof Rustovski bâ-nezd-i saltanat-l seniyyelerine fevka'l- 'âde ve murahhas büyükelçi ta 'yîn etmekliği münâsib addeyledim..." BOA, Y. PRK. NMH, 1-21 v. 1, 10 Nisan 1294 [ 22 Nisan 1878].

${ }^{24}$ BOA. I. HR, 276-16831, 3 Mayıs 1878, BOA. I. HR, 276-16858, 25 Cemaziyelevvel 1295 [27 May1s 1878], Vakit, No: 910, 2 Cemaziyelevvel 1295, 5 Mayıs 1878, s. 1; Basiret, No: 2430, 5 May1s 1878, s. 1; Tercüman-l Şark, No: 26, 5 Mayıs 1878, s. 1, Salname-i Nezaret-i Hariciye, Kostantiniyye, 1302, s. 246, Salname-i Nezaret-i Umur-l Hariciye, Dersaadet 1318, s. 188.

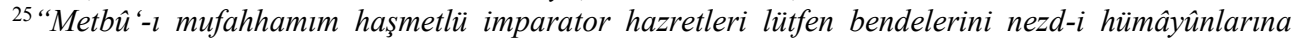
fevka'l-'âde ve murahhas büyükelçiliğe ta'yîn eylemek olduklarından âna dair hâmil olduğum i 'timâdnâmeleri taraf-ı eşref-i pâdişâhîlerine takdîm ederim...”, BOA. Y. PRK. NMH, 1-21 v. 2; Tercüman-ı Şark, No:40, 7 Mayıs 1294 [19 Mayıs 1878].

26 “...Lubanof Rustovski'nin nezd-i şevket-vefir-i mülükânelerinde bu âna değin hâiz olduğu fevka'lâde murahhas büyükelçilik hizmetine hitâm vermişs olduğumuzdan keyfiyeti taraf-l eşref-i pâdişâhîlerine iş 'âr ile 'avdetine müsâ'ade buyurulmasını ricâ ederim ...", BOA. Y. A. HUS. (Yıldız Sadaret Hususi Maruzat Evrakl), 163-13, v. 6, 22 Aral1k 1879.

27 “... cihetle müşâvir-i hâssamız şövalye Novikof'u nezd-i saltanat-l seniyyelerine fevka'l- 'âde murahhas büyükelçi ta 'yîn eyledik müşârûnileyh i 'timâdnâmelerini li-ecli 't-tevdi ' lütfen huzur-ı âlî-i mülûkânelerine kabûl ile...”, BOA. Y. A. HUS, 163-13, v. 7-8, 22 Aralık 1879.

28 "...mâbeyn-i hümâyûn-ı hazret-i mülükâneye 'azîmet etmiş ve huzûr-ı meâl-i nüşûr hazreti mülükâneye dâhil olub...," Vakit, No: 1651, 25 Mayıs 1880, s. 1.

29 “...Osmanlıların padişahı Sultan Abdülhamid Han hazretlerine selâm-ı muhabbet ve meveddetpeyâm-ı imparatorânemizi 'arz eyleriz...”, BOA. Y. A. RES. (Yıldız Sadaret Resmi Maruzat Evrakl), 21-3, v. 3, 8 Şaban 1300 [14 Haziran 1883]
} 
Paşa 16 Ağustos 1889 'da atanmıştır. ${ }^{30} 1883-1897$ yılları arasında İstanbul'da Rus sefaretini temsil eden Nelidov'u Roma sefaretine tayin eden II. Nikola, Nelidov'un Sultan nazarında itibar kazandığını bildirmiş ${ }^{31}$ ve yerine eski Avusturya sefiri Zinovyev'i tayin ettiğini bildirmiştir. Yeni elçinin iki ülke ilişkilerinin devamı adına çaba sarf edeceğini söyleyip kendisine güven duyulmasını istemiştir. ${ }^{32}$ Sultan II. Abdülhamid, bu mektuplara cevaben Nelidov'un aralarındaki dostluk ilişkilerini kuvvetlendirmeye çalıştığını bildirerek kendisinden memnun olduğunu söylemiştir. ${ }^{33}$ Zinovyev 11 Ocak 1898 'de huzura kabul edilmiş ve itimatnamesini sunmuştur. ${ }^{34}$

Petersburg sefiri Hüseyin Hüsnü Paşa, on dokuz sene bu görevde kalmış ve yerine 16 Ağustos 1908 'de Turhan Paşa tayin edilmiştir. ${ }^{35}$ II. Abdülhamid bu tayini bildiren namesini de Livadya'ya gelen II. Nikola’ya bir heyetle göndermiştir. $\mathrm{Bu}$ mektupta Turhan Paşa'nın Petersburg'a tayin edildiğini ve İmparator tarafından da hoş karşılanacağını bildirmiş ve kendisine güven duyulmasını istemiştir. Ayrıca dostluk ve muhabbetlerinin değişmezliğine vurgu yapılmıştır. ${ }^{36}$

\section{Rus İmparatorlarını Kırım'da Karşılama}

Rus imparatorları dinlenmek için Livadya'ya geldiklerinde onlara hoş geldiniz demek adet haline gelmişti. Sultan II. Abdülhamid, bu vesile ile ilişkileri güçlendirmek istemiş ve bir takım siyasi meseleler hakkında imparatorla gönderdiği

${ }^{30}$ BOA. İ. HR. (İrâde Hariciye), 315-20173, 20 Zilhicce 1306, [ 17 Ağustos 1889], BOA. İ. DH. (İrade Dahiliye) 1148-89487, 19 Zilhicce 1306 [16 Ağustos 1889], Mürüvvet, No: 382, s. 1, 5 Ağustos 1305 [18 Ağustos 1889].

31 “...müşârunileyhin müddet-i me'mûriyeti esnâsında beynimizde teyemmünen mevcûd olan münâsebât-ı dostî ve hüsn-i âmiziş te'yîd ve te'kîde ale'd-devâm ...”, BOA. Y. A. RES, 89-4, v. 2, 14, 26 Temmuz 1897.

32 “... Beynimizde teyemmünen cârî olan münâsebât-ı dostânenin mahzûziyet-i mütekâbilemizi mûceb ve teb 'amızca fevâid-i azîmeyi müstelzim olacak sûrette ... fevka'l- âde ve murahhas büyükelçimiz hidmetine müşâvir-i hâssımız şövalye Jan dö Zinovif'i nasb etmeyi münâsib gördüm... ”, BOA. Y. A. RES, 90-104, v. 3, 14 Temmuz 1897.

33 “... müşârunileyhin Dersa 'âdetimizde müddet-i ikâmetinde beynü'd-devleteyn teyemmünen pâyidâr olan revâbıt-ı meveddet ve dostînin teekküd ve takarrürü emrinde muktezâ-yı dirâyet ve fetâneti üzere görülen gayret ve mesâ 'i-i mütemeddiyesini...", BOA. Y. PRK. NMH, 7-51, 3 Cemaziyelevvel 1315, [30 Eylül 1897].

${ }^{34}$ BOA. İ. HUS. (İrâde Husûsî), 60-84, 31 Kanunievvel 1313, [12 Ocak 1898].

${ }^{35}$ BOA. HR. MTV. (Hariciye Nezareti Mütenevvia Klsmı), 3-28, 21 Receb 1326 [19 Ağustos 1908].

36 "...Turhan Paşayl sefâret-i fevkal'âde ile nezd-i haşmet-vefd imparatorilerine i'zâm ve müşârunileyhin...” BOA. Y. EE, 5-169. 
elçiler arasında mülakat yapmayı sağlayarak imparatorun tutumunu öğrenmeye çalışmıştır. ${ }^{37}$ Örneğin 1888 yılında Livadya'ya gelen III. Aleksandr'ı karşılamak için Müşir Fuad Paşa görevlendirmiş ve imparatora mektup göndermişti. Bu mektubunda iki ülke iyi ilişkilerinin sürekli hale getirilmesi temennisinde bulunurken imparatorun bu ziyaretini firsat olarak gördüğünü de belirtmiştir. ${ }^{38}$ Yine 1891 yılında imparatora Fuad Paşa'yla birlikte dostluk içerikli mektup göndermiş ve evliliğinin 25. yılını kutlamıştır. Bu ziyaretlerden ziyadesiyle memnun kalan imparator, mektubunda Fuad Paşa ve Hüseyin Kazım'ı görmesinden dolayı mutlu olduğunu ve beyanatlarını Sultana iletmiş olduklarını ümit ettiğini bildirmiştir. Sultanın kendisine karşı bu nezaket yüklü tutumundan dolayı teşekkür etmiş ve duygulandığını ifade etmiştir. ${ }^{39}$

\section{Cülus Tebrikleri ve Taç Giyme Merasimi}

Sultan II. Abdülhamid'in tahta çıkışını mektup göndererek kutlayan Rus imparatoru II. Aleksandr, geçmişe atıfta bulunarak bir takım üzücü olayların meydana geldiğini fakat bundan sonra barış içerisinde istikrarlı bir iliş̧inin olabileceğini bildirmiştir. $\mathrm{Bu}$ durumun her iki devletin menfaati için önemli olduğunu, kendisinin iyi ilişkiler adına çaba sarf edeceğini bildirmiştir. Fakat barışçıl bir politikanın sürdürülebilmesinin ekseriyetle Sultana bağlı olduğunu belirtmekten de kaçınmamıştır. ${ }^{40}$ Ancak barışçıl söylemlere rağmen bu politika için uygun durum oluşturulamamış ve iki ülke büyük bir savaşla karşı karşıya kalmıştır. Buna rağmen savaşın hemen ardından Ayastefanos Antlaşması'nın imzalandığı 3 Mart 1878 günü II. Aleksandr'ın cülusunun sene-i devriyesi olduğundan Sultan II. Abdülhamid telgraf çekerek imparatoru tebrik etmiştir. ${ }^{41}$

III. Aleksandr, mektubunda babasını suikastla kaybetmenin üzüntüsünü dile getirdikten sonra cülusunu tebliğ etmiştir. Babası tarafından gösterilen dostluk ve

\footnotetext{
${ }^{37}$ Yetimoğlu, Sultan II. Abdülhamid'in Rus Imparatorları İle Mektup Diplomasisi, s. 69-79.

${ }^{38}$ BOA. Y. A. RES, 45-13, v. 2, 8 Safer 1306, [14 Ekim 1888].

39 “....ahiren Kırımdaki ikâmetim esnâsında nezdime bir hey'et-i murahhasa-i fevka'l- 'âde i 'zâmına zât-ı şevketsimât-ı pâdişâhilerince sevk eden niyet-i nâzikânelerinden pek mütehassis olarak bundan ve müşir Fuad Paşa tarafindan yedime teslìm olunan nâme-i muhibbânelerinden dolayı zât-ı şâhânelerine pek hâlisâne teşekkür ederim...”, BOA. Y. PRK. NMH, 5-9, 31 Aralık 1891.

40 “... cülûs-ı hümâyûn-ı mülükâneleri ba'zı hâdisât-ı müellimeye müsâdif bulunmuş ise de ahvâl-i mâziyenin ta 'miriyle ber-musâlaha-ı müstakarrenin istihsâli ...”, BOA. Y. PRK. NMH, 1-3, 27 Şaban 1293 [17 Eylül 1876].

${ }^{41}$ BOA. I. HR, 276-16800, 28 Safer 1295 [3 Mart 1878].
} 
yakınlaşmayı kendisinin de devam ettireceğini bildirmiş ve İstanbul'da bulunan sefirin vazifesine devam edeceğini ilave etmiştir. ${ }^{42}$ Sultan ise cevaben cülus tebrikinde bulunmuş ve imparator ve hanedanı için iyi dilek temennilerinde bulunmuştur. ${ }^{43} \mathrm{Bu}$ üzücü hadise dolayısıyla acılarına ortak olduğunu bildirerek, iki ülke arasında istikrarlı ve kalıcı dostluğun gerekliliğini vurgulamıştır. ${ }^{44}$ III. Aleksandr, babasının suikast sonucu öldürülmesini kendileri açısından olduğu kadar bütün devletler açısından da bir felaket olduğunu, böylesi durumların yaşanmaması ve mevcut düzenin ve barışın korunması için birlik olunması gerektiğini, bunun bir insanlık vazifesi olduğunu bildirmiştir. Bu duygularından sonra Sultanla olan dostluktan bahsederek devamı için herhangi bir engelin bulunmadığını ve ilişkilerin güçlendirilmesi adına çaba sarf edeceğini ve bundan mutluluk duyacağını söyleyerek Sultanın da kendisine destek vermesini istemiştir. ${ }^{45}$

III. Aleksandr'ın taç giyme merasiminde bulunmak ve tebrikleri iletmek için Server Paşa görevlendirilmiştir. Sultan II. Abdülhamid, imparatora gönderdiği mektubunda cülusunun iki ülke arasındaki dostluk ilişkilerine katkı sağlaması temennisinde bulunurken imparatorluk tacının ise tüm Rus halkının sevincine ve övgüsüne nail olacağını belirtmiştir. ${ }^{46}$ İmparator ise cevabında bu vazife için Server Paşa'nın tercih edilmesini gayet olumlu bulmuş ve mutlu olduğunu bildirmiştir. İki ülke dostluk ilişkilerinde büyük hizmetleri bulunan Server Paşa'dan daha müspet bir ismin düşünülemeyeceğini ifade etmiştir. Bundan sonraki süreçte İstanbul'da bulunan sefiri Nelidov'u tam yetkili elçi statüsüne çıkarttığını söylemiştir. ${ }^{47}$

II. Nikola'nın taç giyme merasimine ise eski Paris Sefiri Ziya Paşa gönderilmiştir. Padişah mektubunda kendileri adına Ziya Paşa'nın tebrikte

\footnotetext{
42 “...devleteyn beyninde mevcûd olan ittihâd ve ittifâk iktizâsınca zât-ı meâli-simât pâdişâhîlerinin şu vakı'adan hisse-mend-i teessür olacakları gibi müteveffâ müşârunileyhin izhâr buyurdukları temâyülât-ı dostâneyi hakk-ı senâverlerinde aynen ibrâza devam buyuracakları...", BOA. Y. A. RES, 10-31, v. 4, 4 Mart 1881.

43 “...cülûsunu kemâl-i ihlâs ile tebrîk ederim ve zât ve hanedân-ı hükümrânîlerinin mes'ûdiyetini nâmeleriyle devlet-i fahimânelerinin sa 'adet halini an-samîmü'l-kalb temenni eylerim...”, BOA. Y. PRK. NMH, 2-6, v. 1, 15 Mart 1881.

${ }^{44}$ BOA. Y. A. RES, 10-31, v. 5, 5 Nisan 1881.

${ }^{45}$ BOA. Y. PRK. NMH, 2-6, v. 4, 20 Mart 1881.

46 "... bu def'a bütün Rusyaluları imparatorluğu tâc-l haşmet-ibtihâcî zât-ı fehâmet-simât hükümrânîlerine mazhâriyetle mübâhî olacağından ra'sime-i tebrîk ve tehniyetin icrâsına nezd-i imparatorîlerine fevka'l- 'âde büyükelçilik unvânıyla ...” BOA. Y. PRK. NMH, 2-46, 9 Receb 1300 [16 Mayıs 1883], BOA. Y. A. HUS, 348-34, v.3, 23 Cemaziyelahir 1300 [1 Mayıs 1883].

${ }^{47}$ BOA. A. DVN. NMH. (Bâb-ı Asâfí Divân-ı Hümâyûn Nâme-i Hümâyûn Kalemi), 28-7, 16 Receb 1300 [23 May1s 1883.
} 
bulunacağından ve dostluk temennilerinden bahsetmiştir. ${ }^{48}$ Heyet İmparator ve İmparatoriçe tarafından kabul edilip hoş karşılanmış $^{49}$ ve imparator bu samimiyetinden dolayı Sultana teşekkürde bulunmuştur. Ziya Paşa'yı gördügünden dolayı da mutlu olduğunu beyan etmiştir. ${ }^{50}$

\section{Nişan ve Hediye}

Rus imparatoru III. Aleksandr dostluk ve samimiyetin nişanesi olarak Saint Andre Nişanı ile Sultan II. Abdülhamid'i ödüllendirmek istemiştir. Bu nişanı sefir Nelidov huzura çıkarak Sultana takdim etmiştir. ${ }^{51}$ Bundan memnun olan Sultan, bu nişanın aralarındaki dostluğun delili olduğunu düşünerek memnuniyetini dile getirmiş ve imparatora baht açıklığı temennisinde bulunmuştur. Kendisi de imparatora Murassa Nişan ${ }^{52}$ ve özel olarak yaptırdığ İmtiyaz Nişanı ve eşi Maria Fyodorovna için Şefkat Nişanını hediye etmiştir. ${ }^{53}$ İmtiyaz Nişanının zinciriyle birlikte gönderilmesinden oldukça memnun olan III. Aleksandr, aralarındaki değişmez muhabbetlere dikkat çekerek önceden yapılan sözleşmelerin teminat altına alınmasını gündeme getirmiştir. ${ }^{54}$

III. Aleksandr, hediye olarak Sultan II. Abdülhamid'e kıymetli kürkler göndermiştir. Bu kürkleri alan Sultan oldukça memnun olmuş ve kendisi de imparatora bir takım kumaş ve eşyalar hediye etmiştir. Soğuğa karşı 1sınmak için giyilen kürkleri iki ülke soğuk ilişkilerinin ısınmasına yoran Sultan, imparatorun arzusunun da bu yönde olduğu söyleyerek hediyeleri bu arzunun bir delili olarak

\footnotetext{
${ }^{48}$ BOA. Y.PRK. NMH, 7-3, 6 Zilkade 1313 [19 Nisan 1896], BOA. Y. A. HUS, 348-34, v.2, 23 Cemaziyelahir 1300 [1 Mayıs 1883].

${ }^{49}$ BOA. Y. PRK BŞK. (Yıldız Perakende Başkitabet Dairesi Maruzatı), 46-71, v.2, 5 Muharrem 1313 [16 Haziran 1896].

50 “...icrâ kllnan resm-i tetevvücümüz münâsebetiyle taraf-ı eşref-i hazret-i şehinşâhîlerinden izhar buyurulan eser-i cedîdi hubb u muvâlât ve temenniyât-ı vedâdkârı hüsrevânelerinden dolayı zât-ı hazret-i mülükânelerine beyân-ı teşekkürâtla...”, BOA. Y. EE, 62-11, v. 3, 11 Zilhicce 1313 [24 Mayıs 1896].

${ }^{51}$ BOA. Y. A. HUS, 180-15, 13 Muharrem 1302 [3 Kasim 1884].

52 “... İş bu nişân-l sûret-i meveddet-i beyân beynimizde mevcûd olan muhâdenet-i samimiye- $i$ dostânenin bir dell-i cedîdi ve meveddet-i hâlisa-ı muhibbânemin bir nişâne-i bedîdi edildiği ... ", BOA. Y. PRK. NMH, 3-1, 5 Safer 1302 [24 Kasım 1884].

53 “... Rusya imparatoruyla imparatoriçesi hazerâtına ihdâ buyurulmak üzere sür 'at-i a 'mal-i muktezayl irade-i seniyye-i hazret-i pâdişâhîden olup...”, BOA. I. DH, 936-74107, 19 Safer 1302 [8 Aralık 1884].

${ }^{54}$ BOA. A. DVN. NMH, 30-2, 21 Mart 1303 [2 Nisan 1887].
} 
telakki edeceğini bildirmiştir. ${ }^{55}$ Sultan II. Abdülhamid ile Rus imparatorları arasındaki hediyeleşmelerde sigaralar da önemli bir yer tutmuştur. Nitekim hem Sultanın hem de İmparatorların sigara içiyor olması sigaranın önemini artırmıştır. Sultan, sandıklarla hem III. Aleksandr hem de II. Nikola'ya sigara hediye etmiş hatta özel olarak yaptırdığı tütün masasını II. Nikola'ya göndermiştir. Bu hediyeyi inceleyen imparator böylesine nadide bir eseri görmediğini bildirmiştir. III. Aleksandr ise Sultana zarif bir sigara kutusu hediye etmiş ve "sigara içerken beni hatırlasın" demiştir. Sultan II. Abdülhamid hediyeleri sadece imparatorlara göndermemiş aynı zamanda eşlerini de düşünmüştür. Özel olarak vazolar ve porselen çay takımları yaptırmış ve bunları imparator ve imparatoriçenin zevklerine uygun renklerde imal ettirmiştir. Ayrıca halılar, seccadeler, kumaşlar, II. Nikola'nın vapuru için özel eşyalar ve saat hediye etmiştir. II. Nikola bu hediyeler için Sultana teşekkür ederken saati vapurda bulunduracağını söylemesi Sultanı oldukça mutlu etmiştir. ${ }^{56}$

Sultan II. Abdülhamid'in cülusunun 25. sene-i devriyesini tebrik eden II. Nikola, ayrıca padişaha birtakım hediyeler göndermiştir. Bunlar içerisinde dikkat çeken Grifon Masa Saati'dir. Topkapı Sarayı Müzesi'nde bulunan bu saat üzerinde II. Abdülhamid'in tuğrası ile II. Nikola'nın monogramı bulunmaktadır. ${ }^{57}$

Yapılan hediyeleşmeler iki ülke ilişkilerinde olumlu yankı bulmuştur Nitekim II. Nikola padişahın gönderdiği hediyeleri yeni bir dostluk eseri olarak nitelemiş ve olumlu siyaset takip edeceğini bunun için hükümetine emir verdiğini beyan etmiştir. $^{58}$

Tüm bunlarla birlikte, Sultan II. Abdülhamid'in Ruslara gönderdiği hediyeler Meşveret Gazetesi müdürü Ahmet Rıza tarafından eleştiriye tabi tutulmuştur. Her ne kadar gönderilen hediyenin ne olduğu belirtilmese de pahalı olarak nitelendirdiği hediyelerin tabii olunan hükümdara hanlar ve emirlerin gönderebileceğini

55 “...kürk bürûdete karşu bir kisve olduğundan ve beyn'ed-devleteyn ba'demâ her gûne emâre-i bürûdetin ref" ve izâlesi hakkındaki arzî-yı hükümdârîlerini bildiğimden iş bu hedâye-i behiyeyi bu yoldaki arẑ̂u-yl fehimânelerinin bir delil-i bâhiri olmak üzere telakkî eyler...” BOA. Y. PRK. NMH, 355, 19 Zilkade 1303 [19 Ağustos 1886].

${ }^{56}$ Yetimoğlu, Sultan II. Abdülhamid'in Rus Imparatorları İle Mektup Diplomasisi, s. 137-142.

${ }^{57}$ Feza Çakmut, “Topkapı Sarayı Müzesi'nde Bulunan Saatler”, Topkapı Sarayı'nı Anlatmak, Ed. Ali Satan, Salim Aydın, Selin İpek, Korpus Kültür Sanat Yayıncılık, İstanbul 2018, s. 308.

${ }^{58}$ BOA. Y. PRK. NMH, 6-49, 2 Zilkade 1312 [27 Nisan 1895]. 
söylemiştir. Hükümdarın ise at, kumaş, halı gibi memleketin değerli ürünlerinden hediye edebileceğini bildirmiştir. ${ }^{59}$

\section{Yeni yıl, İsim ve Doğum Günü Tebriki}

Miladı yılbaşlarında Sultan II. Abdülhamid, Rus imparatorlarına, eşlerine ve annelerine telgraf çekerek tebriklerini iletmiştir. Yeni y1lın hem kendileri hem de hanedanları adına mutluluk getirmesi temennisinde bulunmuştur. $\mathrm{Bu}$ vesile ile aralarındaki dostluğa vurgu yapmıştır. Cevabi telgraflarda ise yeni yılın Sultan için de hayırlara vesile olması temennisinde bulunulup teşekkür edilmiştir. Ayrıca imparatoriçeler ise kendilerinin hatırlanmasından ve iltifatlara nail olmalarından dolayı oldukça memnun olmuşlar ve mutluluklarını "an-samîmülkalb if â-yı teşekküre ibtidâr eder" diyerek içten teşekkür etmişlerdir. ${ }^{60}$

Hıristiyanlara özgü olan isim günü kutlaması, Tevrat ve İncil'de geçen aziz ve azizelerin isimlerinin kiliseler tarafından belirlenen günlerde kutlanmasıdır. ${ }^{61}$ Rus imparatorlarından Aleksandr'ın isim günü 11 Eylül, Nikola'nın ise 18 Aralık'tır. Bu tarihlerde Sultan II. Abdülhamid, telgraf çekerek tebriklerde bulunmuştur. Ayrıca Teşrifat-1 Umumiye Nezaret-i tarafindan Rus sefarethanesine özel memurlar giderek imparatorun isim günü tebrik edilmiştir. Bu tebrik 1877 y1lı hariç, Sultan II. Abdülhamid'in saltanatı boyunca muntazaman devam ettirilmiştir. 1879-1884 yıllarında Teşrifat-ı Umumiye Nazırı Münir Bey ile Seryaver Halil Paşa, 1885-1897 yıllarında ise Münir Paşa ile Seryaver Mehmed Paşa Rus sefirine tebriklerini iletmişlerdir. $^{62}$

Osmanlı Devleti'nde doğum günü kutlaması Fuad Paşa'nın girişimleriyle resmilik kazanmış ${ }^{63}$ ve padişahlar da doğum günlerini kutlamaya başlamıştır. II. Abdülhamid'in doğum günlerinde sarayda kutlama yapılırken İstanbul'un birçok yerinde ve taşralarda şenlikler düzenlenmiş ve padişahın doğum günü kutlanmıştır. ${ }^{64}$ Rus imparatorları da telgrafla padişahın doğum gününü kutlamıştır. Nitekim II. Nikola, çektiği telgrafta tebriklerini iletirken dostluğundan bahsederek bu mutlu gün

\footnotetext{
${ }^{59}$ Meşveret, No: 4, 1 Şaban 1313 [17 Ocak 1896].

${ }^{60}$ Yetimoğlu, Sultan II. Abdülhamid'in Rus Imparatorları İle Mektup Diplomasisi, s. 109-112.

${ }^{61}$ Selahattin Çitçi, “Türk Romanında Bir Modernleşme Projesi: İsim Günü Kutlaması”, Rossiskaya Türkologiya No: 1(10), Moskova-Kazan, 2014, s. 30-31.

${ }^{62}$ Yetimoğlu, Sultan II. Abdülhamid'in Rus Imparatorları İle Mektup Diplomasisi, s. 118-122.

${ }^{63}$ Ahmed Cevdet Paşa, Ma rûzât, Yay: Yusuf Halaçoğlu, Çağrı Yayınları, İstanbul 1980, s. 41

${ }^{64}$ Yetimoğlu, Sultan II. Abdülhamid'in Rus Imparatorları İle Mektup Diplomasisi, s. 114-115.
} 
vesilesiyle samimiyetini ortaya koyduğunu bildirmiştir. ${ }^{65}$ Sultan II. Abdülhamid de benzer şekilde imparatorlara doğum günü tebriklerinde bulunmuş ve ayrıca Petersburg büyükelçileri de bizzat sarayda bulunarak imparatorun doğum gününü kutlamıştır. Örneğin Hüseyin Hüsnü Paşa 10 Mart 1892'de III. Aleksandr'ın doğum günü tebrikinde imparatorla görüşmüş ve imparator, Sultan II. Abdülhamid'in sihhatini sormuş ve dostluğundan söz etmiştir. ${ }^{66}$

\section{9. İzdivaç ve Doğum Tebrikleri}

Rus imparatorları hanedanlarında meydana gelen evlilik ve doğumları Sultan II. Abdülhamid'e bildirmeyi adeta vazifeden saymışlar ve bu mutlu günde padişahın da aynı sevinci paylaşacağını düşünmüşlerdir. Örneğin III. Aleksandr, kardeşi Serj (Sergei) Aleksandroviç'in Hesse Grandükasının kızı Elizabet Aleksandra ile izdivacını bildirdiği mektubunda “...mesâr olan iş bu vâkı 'a-yı mübtehîcenin dahi taraf-ı eşref-i hazret-i pâdişâhîlerine iş 'ârını bir vazîfe-i nazîfeden add eder..." ifadelerine yer vermiştir. ${ }^{67}$ II. Nikola ise Olga adını verdiği bir kızı olduğunda “...bir kız çocuğu dünyaya getirüp Olga tesmiye kllınmış olduğunu taraf-ı eşrefi cenâb-ı şehinşâhîlerine ma 'al-memnûniye iş 'ar eylerim..." diyerek bildirmiştir. ${ }^{68}$ Birçok izdivaç ve dünyaya gelen çocukların muştu haberine karşın Sultan II. Abdülhamid benzer şekilde cevaplar vererek sevinçlerine ortak olduğunu bildirmiş ve dostluğuna dikkat çekmiştir. ${ }^{69}$

\section{0. Şifa Dilekleri ve Taziye Mesajları}

II. Aleksandr, 14 Nisan 1879'da sarayın bahçesinde dolaşırken kendisine dört el ateş edilmiş fakat isabet etmemişti. ${ }^{70}$ Bunu haber alan Sultan II. Abdülhamid, geçmiş olsun dileklerinde bulunmuş ve bu elim hadiseden üzüntü duyduğunu aynı

\footnotetext{
65 “...velâdet-i humâyûn-ı mülükâneleri rûy-ı fîrûz vesilesiyle tebrikâtımı en samimi olan temenniyâtımı zât-ı hazret-i pâdişâhîlerine arz ve beyân ve muhabbet-i lâ-yetegayyerem te'minâtın tecdîd eylerim. BOA. Y. PRK. NMH, 9-3, 20 Ekim 1902.

${ }^{66}$ BOA. Y. PRK. ESSA. (Yıldız Perakende Elçilik, Şehbenderlik ve Ateşemiliterlik), 15-51, 9 Mart 1892 [21 Mart 1892] BOA. Y. A. HUS, 257-139, 28 Şaban 1309 [28 Mart 1892].

${ }^{67}$ BOA. Y. A. HUS, 179-90, v. 3, 30 Haziran 1884.

${ }^{68}$ BOA. I. HR, 350-34, v. 112 Kasim 1895.

${ }^{69}$ Ayrıntılı bilgi için bkz: Yetimoğlu, Sultan II. Abdülhamid'in Rus Imparatorları Ile Mektup Diplomasisi, s.129-134.

${ }^{70}$ Vakit, No: 1249, 3 Nisan 1295 [15 Nisan 1879].
} 
zamanda imparatorun sıhhatine halel gelmediği için de mutlu olduğunu bildirmiş ve uzun ömürler dilemiştir. ${ }^{71}$ Livadya'ya dinlenmek için gelen III. Aleksandr, burada hastalanmış ve durumu her geçen gün kötüye gitmiştir. Sultan II. Abdülhamid, imparatorun sağlığını yakından takip etmiş, imparatorun eşi, kardeşi ve çocuklarına telgraf çekerek üzüntüsünü dile getirmiş ve bilgi almıştır. Aynı zamanda imparatorun durumuyla ilgili olarak haberdar etmelerini istemiştir. Fakat akciğerinde iltihap bulunan imparatorun ağzından öksürdükçe kan gelmiş ve hayatını kaybetmiştir. ${ }^{72}$

Sultan II. Abdülhamid, III. Aleksandr'ın ölümünü haber alınca, II. Nikola’ya gönderdiği telgrafta babasının ölümünden dolayı müteessir olduğunu, kendisiyle iyi ilişkiler kurduğunu ve dost olduğunu bildirerek tüm aile fertlerine taziyelerini bildirmiş ve sabırlar dilemiştir. Bu taziye mesajlarına karşın ölen imparatorun eşi, çocukları ve kardeşleri ayrı ayrı cevabi telgraflar göndermişler ve acılarına ortak olmasından ötürü kendisine minnettar olduklarını dile getirmişlerdir. ${ }^{73}$ II. Nikola ise Sultan II. Abdülhamid'in bu teveccühünü kurulacak yeni dostlukların delili olarak görmüş ve babası dönemindeki iyi ilişkileri devam ettireceğine dikkat çekmiştir. ${ }^{74}$

Böylece Sultan II. Abdülhamid, Berlin Antlaşması sonrasında oluşan yeni dünya dengelerine göre politikalar yürütmüş, Rus imparatorlarıyla yeni bir çatışmadan kaçınmıştır. Yukarıda sayılan birçok konuyu, ülkeler arası iyi ilişkiler için araçsallaştırmıştır.

\section{Sonuç}

Sultan II. Abdülhamid, 33 yıl süren hükümdarlığı boyunca mevkidaşı üç Rus imparatoruyla diplomatik temasta bulunmuştur. 93 Harbi'nden sonra diplomatik ilişkilere büyük önem vererek, dış siyasette Rusya ile iyi geçinmeye çalışmıştır. Bu bağlamda Ermeni, Girit ve Bulgaristan meselelerinin çözümünde bölgeyi yakından

\footnotetext{
71 “...bu haberden ne derece müteessir oldum ise masûniyet-i imparatorîleri haberinden dahî o derece memnûn oldum bundan dolayı îfâ-yı tebrîkât ile berâber temâdi-i eyyâm-ı ömr ü haşmetpenâhîleri duâsını bi-hulûsü'l-bâl yâd ve tezkâr eylerim...”, BOA. Y. PRK. NMH, 1-52, v. 1, 21 Rebiülahir 1296 [14 Nisan 1879].

72 Yetimoğlu, Sultan II. Abdülhamid'in Rus Imparatorları İle Mektup Diplomasisi, s. 147-148.

${ }^{73}$ Yetimoğlu, Sultan II. Abdülhamid'in Rus Imparatorları İle Mektup Diplomasisi, s. 151-152.

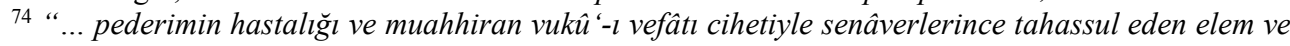
keder-i azîmeye iştirâk buyurarak hazıra-ı ebediyesi muhlislerince pek ziyâde kıymetdâr olan meveddet-i muhâleset-i hümâyûn-ı mülükânelerinin yeni bir delîlini ibrâz buyurmuşlardır...”, BOA. Y. PRK. NMH, 9-99, v. 24, 28 Kasim 1894].
} 
takip eden Rusya ile temasa geçmiştir. Ermeni sorunu kısmen çözüme kavuşmuş olsa da Girit’te beklenilen yardım alınamamıştır. Bulgaristan'da ise kendi çıkarlarını göz önünde bulunduran Rusya, bir müddet Bulgar mezalimini durdurmuştur. Siyasi meselelerin çözümünde kısmi başarı elde eden Sultan II. Abdülhamid, daha çok Osmanlı-Rus ilişkilerinin saltanatı boyunca olumlu seyretmesinde başarılı olmuştur. Diplomasinin gücüne inanarak ilişkilerini bu minval üzere devam ettirmiştir.

$\mathrm{Bu}$ olumlu ilişkiler karş11kklı olarak devam etmiştir ki Sultan II. Abdülhamid'in cülusunu tebrik eden II. Aleksandr, iyi ilişkiler kurmak istediğini ama bunu sağlamanın yolunun Sultandan geçtiğini belirtmesi karşılıklılık esasını ortaya koymaktadır. Tahta geçen imparatorlar, dostluk ilişkilerini devam ettireceklerini her seferinde dile getirmişlerdir. Sultan II. Abdülhamid'in, imparatorlar yanında imparatoriçelerle de diplomatik temas kurması iki ülke ilişkileri açısından oldukça manidardır. Rus hanedanının sevinç ve üzüntülerinin diplomatik usullere paylaşılması, devletlerarası ilişkileri geliştirmiştir. $\mathrm{Bu}$ dostluklar, mektuplarda nazikâne bir dille aktarılmıştır. Hediyeleşmeler de dostluğun tesisinde oldukça önemli bir yer tutmuştur. İmparator ve imparatoriçeler için özel olarak yaptırılan vazo ve çay takımlarının onların zevkine uygun renkte olması, yine özel olarak İmtiyaz ve Şefkat nişanlarının yaptırılması büyük bir nezaket ve incelik olarak değerlendirilmiştir. III. Aleksandr'ın hediye ettiği kürkleri, soğuyan iki ülke ilişkilerinin tekrar 1sınması şeklinde okunması, hediyelerde sembollerin kullanıldığın bir göstergesidir.

Bunların yanında Rus imparatorlarının taç giyme merasimlerine ve hoş geldiniz demek için Livadya'ya elçilik heyeti gönderilmesi de imparatorlar tarafından büyük yankı uyandırmıştır. Yapılan tüm diplomatik girişimler iki ülke dostluk ilişkilerinin devamı adına bir basamak oluşturmuş ve olumlu etkide bulunmuştur. Rus imparatorları Sultan II. Abdülhamid'i dost olarak nitelendirmişler ve hanedanlarına ait mutlu ve üzücü hadiseleri bildirmeyi adeta vazife saymışlardır. Böylece 93 Harbi'nden sonra takip edilen 1lımlı diplomasi nedeniyle, iki ülke ilişkileri savaşsız biçimde Sultan II. Abdülhamid'in saltanatını sonuna kadar devam etmiştir. 


\section{KAYNAKÇA}

\section{1-Arşiv Belgeleri}

\section{Başkanlık Osmanlı Arşivi (BOA)}

Bâb-ı Asâfî Divân-ı Hümâyûn Nâme-i Hümâyûn Kalemi, (A. DVN. NMH), 28-7, 302.

Hariciye Nezareti Mütenevvia Klsmı (HR. MTV), 3-28.

Irâde Dâhiliye (İ. DH), 1148-89487, 936-74107.

Irâde Hariciye (İ. HR), 276-16831, 276-16858, 315-20173, 276-16800, 350-34.

İâde Husûsî (İ. HUS), 60-84.

Tercüme Odası Belgeleri (HR. TO), 286-28.

Yıldız Esâs Evrâkı (Y. EE), 5-169; 13-19-3-2; 62-11; 114-58.

Yıldız Perakende Başkitâbet Dâiresi Maruzatı (Y. PRK. BŞK), 46-71.

Ylldı Perakende Elçilik, Şehbenderlik ve Ateşemiliterlik (Y. PRK. EŞA), 15-51.

Yıldız Perakende Nâme-i Hümâyûnlar (Y. PRK. NMH), 1-3; 1-21; 1-29; 1-52; 1-56; $2-6 ; 2-46 ; 3-1 ; 3-55 ; 5-9 ; 6-49 ; 7-3 ; 7-51 ; 7-79 ; 7-98 ; 8-7 ; 9-3 ; 9-99$.

Yıldız Sadaret Husûsi Maruzat Evrakı (Y. A. HUS), 163-13; 179-90; 180-15; 34834; 257-139.

Yıldız Sadaret Resmi Maruzat Evrakı (Y. A. RES), 10-31; 21-3; 45-13; 89-4; 90-104.

\section{Süreli Yayınlar}

Basiret, No: 2430.

Meşveret, No: 4.

Mürüvvet, No: 382.

Tercüman-ı Şark, No: 26, 40.

Vakit, No: 910, 1249, 1651.

Salname-i Nezaret-i Hariciye, 1302, Kostantiniyye 1302.

Salname-i Nezaret-i Umur-ı Hariciye,1318, Dersaadet 1318.

\section{Kitaplar ve Makaleler}

Ahmed Cevdet Paşa, Ma'rûzât, Yay: Yusuf Halaçoğlu, Çağrı Yayınları, İstanbul 1980.

Binark, İsmet; "Başbakanlık Osmanlı Arşivinde Mevcut Name-i Hümayun Defterlerine Göre Osmanl1-Rus Münasebetleri”, Türk-Rus İlişkilerinde 500 Yll (1491-1992), TTK Yayınlar1, Ankara 1999, ss. 197-207.

Çakmut, Feza, “Topkapı Sarayı Müzesi'nde Bulunan Saatler”, Topkapı Sarayı'nı Anlatmak, Ed. Ali Satan, Salim Aydın, Selin İpek, Korpus Kültür Sanat Yayınc1lik, İstanbul 2018, ss. 290-309. 
Çitçi, Selahattin; "Türk Romanında Bir Modernleşme Projesi: İsim Günü Kutlaması", Rossiskaya Türkologiya No: 1(10), Moskova-Kazan, 2014, ss. 29-34.

İnalcık, Halil; “Osmanl1-Rus İlişkileri 1492-1700”, Türk-Rus İlişkilerinde 500 Yll 1492-1992 Ankara 12-14 Aralk 1992, Türk Tarih Kurumu Yayınları, Ankara 1999, ss.25-35.

Karal, Enver Ziya; Osmanlı Tarihi VIII, Birinci Meşrutiyet ve İstibdat Devirleri (1876-1907), TTK, Yayınları, Ankara 2011.

Kurat, Akdes Nimet; Rusya Tarihi Başlangıçtan 1917'ye Kadar, Türk Tarih Kurumu Yayınları, Ankara 2014.

Mahmud Celaleddin Paşa, Mir'ât-i Hakîkat, C. I-II-III Haz: İsmet Miroğlu, Berekât Yayınları, İstanbul 1983.

Osmanl Belgelerinde Ermeni Rus İlişkisi (1899-1906), C. II, Yay. Haz: Recep Karacakaya ve diğerleri, Başbakanlık Devlet Arşivleri Genel Müdürlüğü Osmanlı Arşivi Daire Başkanlığı Yayını, Ankara 2006.

Öztürk, Yücel; “Osmanlı Devleti’nin Rusya'ya Yönelik Dış Politikası ve TürkiyeMoskova İlişkileri (16. ve 17. Yüzyıllar), Türk Dış Politikası Osmanlı Dönemi, Ed. Mustafa Bıyıklı, Bilimevi Yayınları, İstanbul 2008, ss. $217-$ 280.

Pritsak, Omeljan; “1491-1532 Y1llarında Osmanlı-Moskova İlişkileri”, Türk-Rus Illişkilerinde 500 Yll 1492-1992 Ankara 12-14 Aralık 1992, Türk Tarih Kurumu Yayınlar1, Ankara 1999, ss. 65-71.

Yetimoğlu, Halil; Sultan II. Abdülhamid'in Rus Imparatorları Ile Mektup Diplomasisi, Bozok Üniversitesi Sosyal Bilimler Enstitüsü Tarih Anabilim Dalı, Yayımlanmamış Yüksek Lisans Tezi, Yozgat 2019. 